\title{
Hertug Hans den Ældre
}

af TROELS FinK

I 1994 var Troels Fink med til at udgive det store værk "De Hansborgske Domme 1545-1578«. På 1400 sider gengiver værket de over 700 domme, som blev afsagt af hertug Hans den Ældre og hans administration i Haderslev. Til denne store kildeudgave skrev Troels Fink en sammenfattende redegørelse for Hertug Hans' liv og virke. Beretningen fortjener at komme ud til en bredere læserkreds.

Kong Frederik I var gift to gange. Første gang med Anna af Brandenburg, som døde i 1514. Anden gang i 1518 med Sofie af Pommern.

I første ægteskab var der to børn. Christian, født 1503, den senere Christian III og Dorothea, født 1504. Hun blev i 1526 gift med hertug Albrecht af Preussen, d.v.s. Østpreussen. I Frederik I's andet ægteskab var der fem børn. Hans, født 1521, Elisabeth, født 1524 (hun blev gift med hertug Magnus af Mecklenborg og efter hans død med hertug Ulrik af Mecklenborg), Adolf, født 1526, Dorothea, født 1528 (gift i den modne alder af 45 år med hertug Christoffer af Mecklenborg) og endelig Frederik, født 1532.

Her er det Hans, det gælder. Han går i historien under betegnelsen Hans den Ældre; dette tilnavn har han fået for at kunne holde ham ude fra hans nevø Hans den Yngre, der var søn af Christian III. Tilnavnet »den Ældre« blev først nødvendigt i 1572, da Hans »den Yngre« overtog Als og Sundeved som sit lille hertugdømme.

Prins Hans voksede op $i$ en meget urolig tid. Da han blev født, regerede endnu hans fæetter Christian II som konge i Danmark, medens hans far, Frederik, som hertug havde det halve af Sønderjylland og det halve af Holsten, kongen havde den anden halvdel af hvert hertugdømme.

I 1523 kom begivenhederne i skred, Christian II så sig nødsaget til at forlade landet, og hertug Frederik blev valgt til konge af Danmark. Men Christian II havde stadig mange tilhængere, ikke mindst blandt bønderne i den kongelige del af Sønderjylland. I 1532 blev Christian II lokket i en fælde og blev fange på Sønderborg Slot.

Perioden var også kendetegnet ved et voldsomt røre om kirkens 
forhold. Luthers lære bredte sig, og den fik en varm fortaler i den senere Christian III. Hans far havde i 1526 indsat ham til at styre Haderslev amt. Her gennemførte han på egen hånd $\mathrm{i}$ de følgende år en reformation, mens kong Frederik søgte at balancere mellem katolikker og protestanter, dog med en stille forkærlighed for de sidste. Men det katolske parti var stadig en stærk faktor, og de ledende i denne kreds imødeså med bekymring, at Christian skulle blive konge af Danmark. De skrev i 1529 til kong Frederik for at bede om, at prins Hans måtte blive sendt til Danmark, for at han engang kunne få Danmarks rige. Meningen var, at han skulle opdrages i den katolske tro og lære det danske sprog og få kendskab til danske traditioner. Kong Frederik gik ind på tanken og lod sønnen drage til kongeriget. Et par år senere fik prins Hans anvist indtægterne af Nyborg len, og Oluf Rosenkrantz til Vallø blev hans hofmester. Rosenkrantz måtte svigte Vallø og for en tid tage ophold på Nyborg slot for til stadighed at kunne tage sig af den unge prins.

I 1533 døde Frederik I og så brød et uvejr løs. Der var strid om tronfølgen, og der blev udfoldet bestræbelser for at få Christian II tilbage. Dertil kom konflikten mellem de to religiøse retninger, og rejsninger af borgere og bønder. Katolikkerne opnåede at få kongevalget udskudt, og de holdt derved pladsen åben for prins Hans, men da det kom til stykket sejrede protestanterne, Christian blev i 1534 valgt til konge. I maj samme år blev der indledt et angreb mod Danmark med grev Christoffer af Oldenborg som leder og Lübeck som drivkraft, formelt for at genindsætte Christian II, men der var mange krydsende interesser i den krig, som går under navnet Grevens Fejde (1534-36).

Da Oluf Rosenkrantz hørte om Lübeckernes indfald i Holsten, sendte han 50 landsknægte til Sønderborg for at forstærke bevogtningen af Christian II.

På Fyn brød et almueoprør løs. Dalum kloster blev stormet af en ophidset mængde, og Hagenskov slot blev indtaget af en folkeskare. Oluf Rosenkrantz blev bange for, at urolighederne kunne ramme prins Hans. I forklædning flygtede han med prinsen og et lille følge til det velbevogtede Sønderborg slot.

Det var mens prins Hans opholdt sig her, at Christian III den 4. juli 1534 af de jyske rigsråder blev valgt til konge. Efter slaget ved Øksnebjerg på Fyn 11. juni 1535 fik Christian herredømmet over denne $\varnothing$, og det fortælles, at prins Hans for en stund vendte tilbage til 


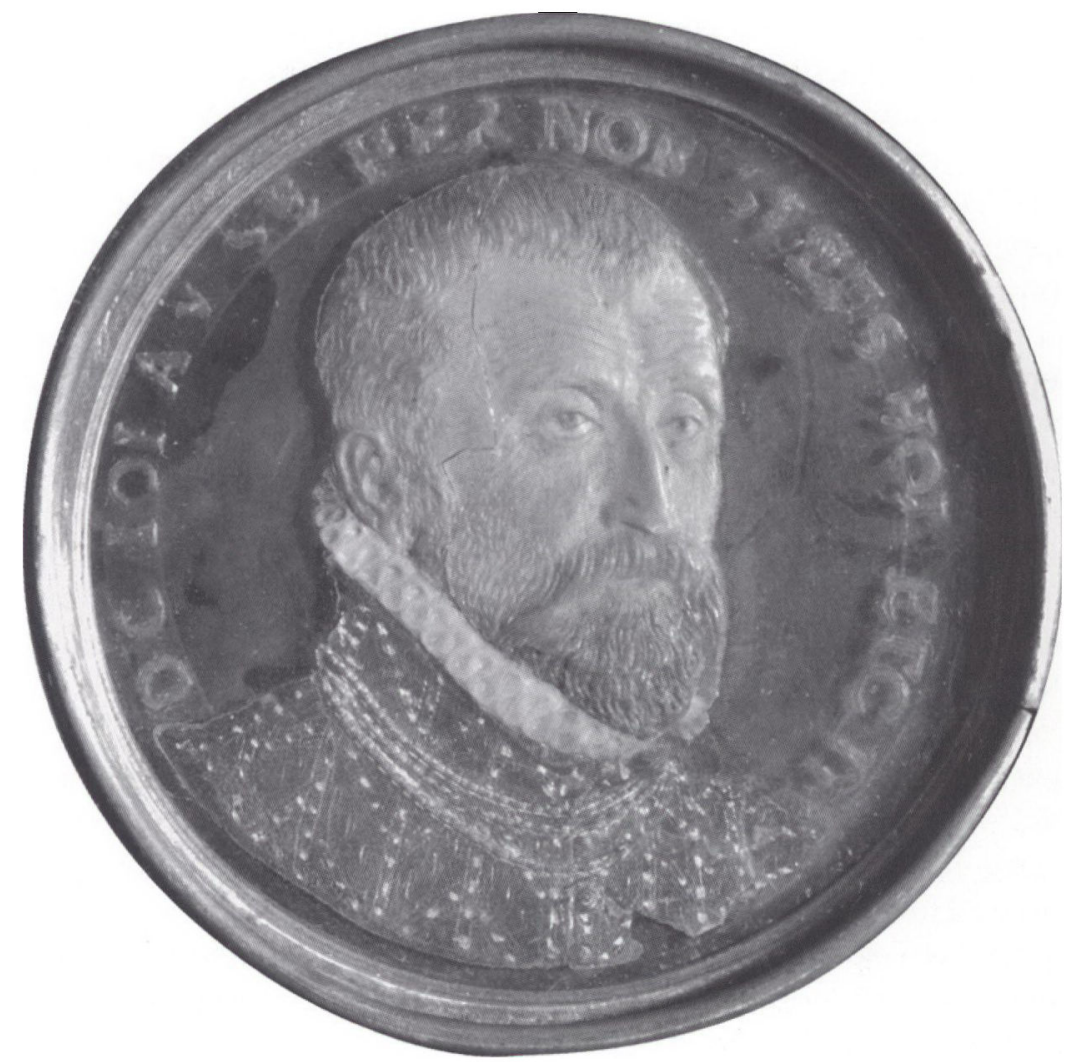

Voksmedalje af hertug Hans den Aldre udfort af den tyske medaillor Valentin Maler $i$ 1573. Portrættet er formentlig udfort $i$ Sachsen, hvor hertug Hans dette år besøgte sin niece Anna, gift med hertug August. Portrattet opbevares pd Historisches $M u-$ seum $i$ Dresden. Her gengivet efter foto $i$ Haderslev Museum.

Nyborg. Muligheden for, at han kunne blive konge, var dog for stedse forbi. Året efter blev han sendt til Königsberg for at komme i "fyrstelære" hos sin svoger hertug Albrecht og sin søster hertuginde Dorothea. Han ankom til Königsberg med et lille følge den 4. sept. 1536. Som hofmester fik han Caspar von Rechenberg. Hertug Hans var nu 15 år gammel.

Under opholdet i Østpreussen udviklede der sig et nært forhold mellem den unge prins og hertugparret. I den første tid var det især søsteren, hertuginde Dorothea, der tog sig af ham, senere var det hertugen selv. 
Det første år voksede den unge prins, så han efter Hertug Albrechts beskrivelse til Christian III virkede som en lemmedasker; armene hang på ham, og han slæbte på fødderne. Kongen troede, det var en sygdom, men det var kun vokseværk. Skolegangen var endnu ikke forbi. Det boglige lå ikke for ham. Prins Hans bad så mindeligt om at slippe for at lære latin, og hertugen spurgte svogeren i Kobenhavn, om prins Hans kunne nøjes med at lære tysk og tysk historie; afgørelsen overlod kongen til hertug Albrecht. Prins Hans slap for latinen, men han brød sig heller ikke om at skrive. Han satte nødig selv pennen til papiret. Det havde han andre til. Adskillige gange undskyldte han, at han ikke skrev egenhændigt. I 1548 gav han også den begrundelse, at han havde indladt sig for meget med fremmede herrer og drukket for meget til at kunne klare skriveriet.

Opholdet i Königsberg varede i 6 år, og det prægede ham for livet. Det tyske fyrsteideal stod for ham, som det han skulle følge. Opholdet i Nyborg synes ikke at have sat sig spor. Da han rejste hjem, fik han et smukt vidnesbyrd med sig. Han var »from, ærlig, redelig og gudfrygtig «. Det indtryk får man også, når man betragter hans senere liv.

I 1542 forlod prins Hans Königsberg, og i 1543 blev han med den erfarne feltherre Johan Rantzau ved sin side statholder i Sønderjylland og Holsten.

Grevens Fejde var nok endt i 1536, men også de følgende år var meget vanskelige for Danmarks rige. Den tilfangetagne Christian II sad nu som før på Sønderborg Slot, og han kunne stadig regne med støtte flere steder i Europa, og i årene 1542-44 kom det til regelret krig med Nederlandene, og det berørte i høj grad prins Hans som statholder. Med en fred i Speyer i 1544 sluttede denne krig, og en lidt mere rolig periode begyndte.

Det betød også, at Christian III nu kunne få gennemført den deling af de to hertugdømmer, som han havde lagt op til, da stænderne efter Frederik I's død havde hyldet alle dennes fire sønner.

\section{Hertugdømmernes deling}

Hertugdømmernes forhold var dengang som senere meget komplicerede. Det slesvig-holstenske ridderskab havde i 1460 valgt kong Christian I til hertug af Slesvig og greve af Holsten "for den gunst de havde til hans person«, og mange af ridderskabsmedlemmerne havde håbet på en deling mellem kongens to sønner Hans og Frederik på 
den måde, at Hans fik kongeriget og Frederik hertugdømmerne, men Hans var stærk nok til at hævde, at også han havde arveret. Den valgret, der var udøvet i 1460, blev en episode, for i Tyskland var fyrstedømmerne arvelige.

I 1490 blev der opnået et kompromis. Hertugdømmerne skulle udadtil optræde som en enhed, men regeret af to fyrster. De to skulle $i$ fællesskab have ridderskabet under sig og ligeledes den fælles stænderlanddag, men indtægterne skulle deles ligeligt; de kom fra lenene, de to fyrster fik len eller amter både i Slesvig og Holsten. I amterne regerede hver fyrste for sig. Princippet fra $1490 \mathrm{blev}$ gentaget i 1544 . I kongeriget var man godt tilfreds med dette princip, for det betød, at yngre prinser ikke kom til at tynge på den kongerigske pengekasse. I dette år deltes hertugdømmerne på ny, men denne gang mellem tre fyrster. Ridderskabet kæmpede for det størst mulige fællesskab mellem delene; bl.a. mente de adelige, at hvis fyrsterne fik fælles råder, så ville disse råder kunne sikre en fælles politik, men det afviste fyrsterne; hver af dem fik sine egne råder, men taget blandt ridderskabets medlemmer. Det føltes som et stort nederlag for ridderskabets førende skikkelse Johan Rantzau; han trak sig krænket tilbage fra sine politiske poster.

De tre dele fik navn efter henholdsvis Haderslev, Sønderborg og Gottorp. Det første område tilfaldt hertug Hans, det andet kongen og det tredje gik til hertug Adolf. Hertug Hans fik Haderslev amt og Tørning len, dertil det store Tønder amt med de frisiske øer bortset fra Amrum, Vesterland-Før og nordspidsen af Sild, der hørte til kongeriget, dertil Rendsborg og øen Femern, der var en del af hertugdømmet Slesvig, selvom den lå ud for Holstens kyst. Hertug Hans fik også Løgumkloster og Bordesholm kloster i Holsten.

Sønderborg-delen strakte sig tværs over landet via Flensborg til Bredsted. Gottorp-delen omfattede Slesvig og Husum amter samt Ejdersted, og for at få regnestykket til at gå op kom også det lille Aabenraa amt under Gottorp. Den yngste bror, Frederik, blev affundet med Slesvig bispegods. I Holsten var lenene mindre, fordi de adelige godser her var så omfattende.

De fælles opgaver var især forholdet til udlandet, og de forpligtelser fyrsterne på Holstens vegne havde over for Det tyske rige. Ingen af de to unge fyrster tog residens i Holsten; i Slesvig var de friere end i Holsten, hvor rigsmyndigheden i givet fald kunne gøre sig gældende. Der blev nu og da udstedt fælles forordninger, men det var kun 


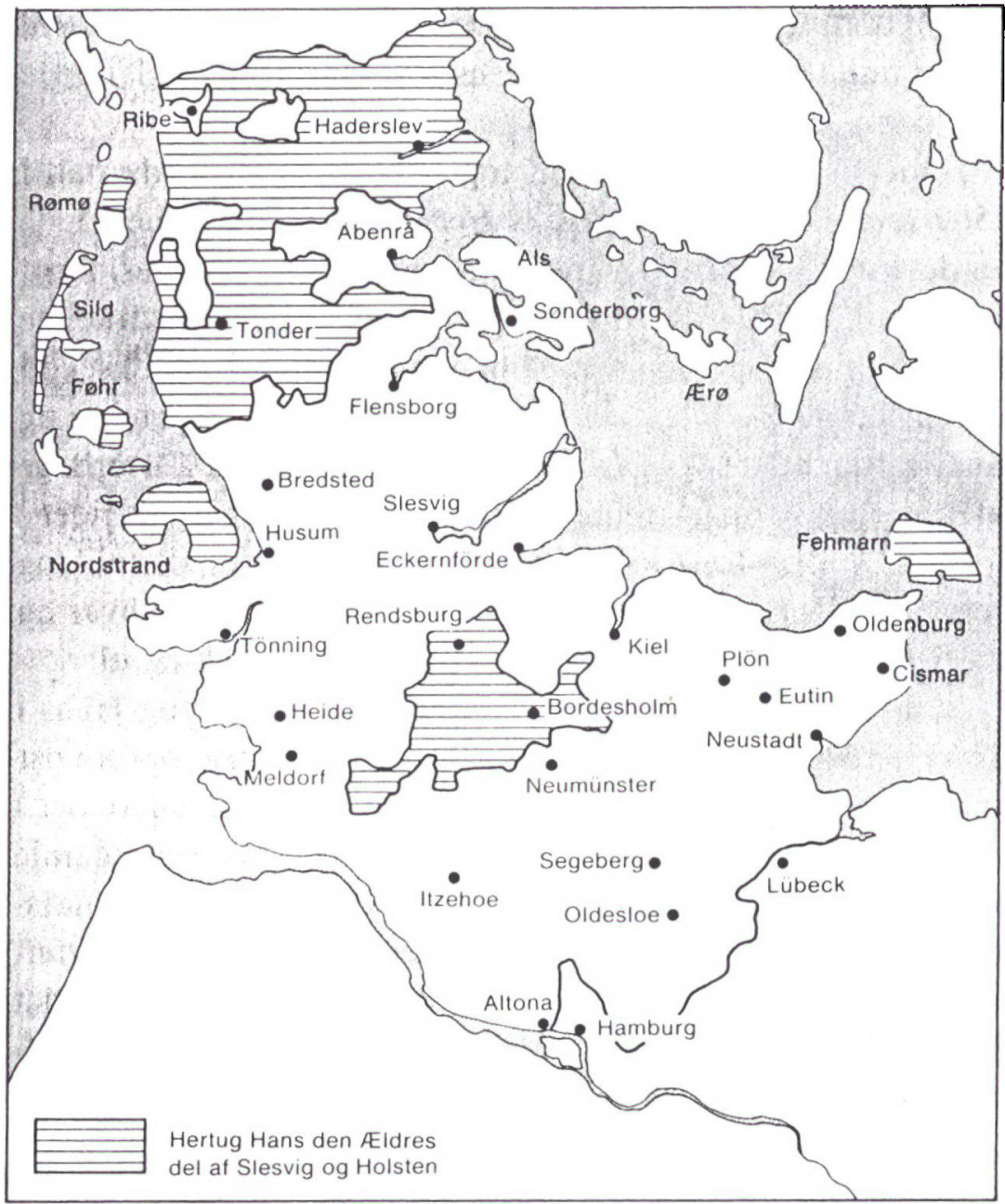

Hertug Hans den Aldres del af Slesvig og Holsten ved delingen $i$ 1544. Kort $i$ H. V. Gregersen: Slesvig og Holsten for 1830 (1981) s. 269.

på begrænsede og specielle områder bortset fra en Rettergangsordning fra 1576.

I begyndelsen var det lidt tilfældigt, hvordan fælles-styret blev ledet, men fra 1564 gik ledelsen på skift for et år ad gangen med Mikkelsdag (30. september) som skiftedag.

Nogle af ridderskabsmedlemmerne havde håbet, at den distrikts- 
blanding, der var afstedkommet i 1544, trods alt ville tvinge fyrsterne til at samarbejde; det skete kun i begrænset omfang. De to unge fyrster satte alle kræfter ind på at skaffe sig den størst mulige selvstændighed.

Kongen indtog en helt anden stilling end de to medfyrster. Han måtte som konge af Danmark også varetage rigets interesser; og for den kongelige dels vedkommende kunne en følelse af en sammenhæng med Danmark bevares.

De to hertuger ønskede størst mulig uafhængighed af Danmark, mens kongen krævede Danmarks lensoverhøjhed over Sønderjylland respekteret. De to hertuger ville nok formelt anerkende, at det forholdt sig således, men de ville ikke yde bistand til kongeriget i tilfælde af krig. Der blev forhandlet vidt og bredt om dette problem næsten så længe hertug Hans levede. Endelig i 1579 nåede man et resultat. Hertugerne gik med til en nærmest symbolsk bistand til riget i tilfælde af krig med 40 ryttere hver. Lensoverdragelsen blev derpå fejret med stor pragt i Odense.

Omvendt fandt de to hertuger det helt naturligt, at kongeriget kom hertugdømmerne til hjælp, hvis grænserne her var truet.

I forholdet til det tysk-romerske rige var det lettere for alle tre fyrster at opnå enighed. Linien var ganske klar, de søgte alle tre at reducere deres pligter til det mindst mulige.

I hertugdømmerne havde medlemmerne af ridderskabet monopol på amtmandsposterne, og deres stilling var så meget stærkere, som de fleste amter var pantsat til dem. Hertug Hans måtte i 1544 overtage en gæld på 50.000 mark lybsk. Af dette beløb havde amtmand Jesper Rantzau på Haderslevhus 3000 mark til gode til 6\% rente, Schack Rantzau på Femern stod for 10.000 mark, Claus v. d. Wisch sad på Tønder Slot med en fordring på 12.000 mark og Kaj Rantzau havde Rendsborg i pant for 12.000 mark, det var ialt 37.000 mark af de 50.000.

Det var en drøj opgave for den unge fyrste at indløse panthaverne, og allerede dagen efter den officielle deling, den 9. august 1544, skrev hertug Hans til sin svoger hertug Albrecht i Königsberg for at bede om et lån på 30.000 mark lybsk. Svaret lød, at hertug Albrecht ikke havde for meget selv, men han kunne dog yde hertug Hans et lån på 10.000 mark for et år. Pengene skulle bruges til at indløse så mange af de pantsatte amter som muligt. Det lykkedes hertug Hans i løbet af få år at komme ud af sin gæld. Netop da han begyndte sin regering, satte en højkonjunktur ind; de trange tider blev afløst af fede år. 


\section{Administrationen opbygges}

I august 1544 flyttede hertug Hans ind på Haderslevhus. Slottet var stærkt forfaldent; hans bror Adolf kaldte det en røverrede. Blandt de pantsatte len var Haderslevhus det første, som hertug Hans indløste, og i den gamle "røverrede" indrettede han sig med sin administration.

Fra Königsberg havde han fået sin hovmester Casper v. Rechenberg med sig; denne havde også i 1543-44 hjulpet hertugen, da han var statholder. Caspar v. Rechenberg blev et par år ved hertugens side.

Selve kancelliet blev imidlertid indrettet af en anden embedsmand med baggrund i Østpreussen. Det var Georg Corpes.

Allerede i 1543, mens hertug Hans residerede på Gottorp, var der indrettet en registrant, d.v.s. en kopibog, og den fortsatte man med efter den 9. august 1544, da hertugen begyndte sit regimente. Efterhånden blev registranterne delt op i rækker. Den første omfattede de såkaldte lukkede breve, skrivelser til enkeltpersoner; af denne række er bevaret 11 folianter. Tilsvarende blev brevene til udlandet samlet $i$ en række, den nåede i årenes løb op på 4 bind. Yderligere var der de åbne breve, breve der skulle komme til offentligt kendskab, de såkaldte patenter. Disse udgjorde sammen med dommene 3 bind. De indgåede breve blev samlet $\mathbf{i}$ aktpakker. Deraf er mange bevarede, men ikke så fuldstændigt som de udgåede breve.

I 1570 udstedte hertugen en kancelliordning, der vel var en bekræftelse på den faktiske tilstand på denne tid. I de forste år har der næppe været en speciel juridisk ekspertise i kancelliet, men i 1564 ansatte hertugen en juridisk doktor ved navn Poul Neidhart i kancelliet. Ham kender man ikke meget til. Men i 1569 blev dr. Hieronymus Oelgarth kansler, og han blev i embedet, så længe hertug Hans levede. Ved hans side var der en sekretær, først Hieronimus Boldek og siden Georg Beyer.

Gennem kancelliordningen kan man nogenlunde se, hvordan arbejdet var organiseret. Skriverne - de kaldtes »kancellisvende « - skulle om sommeren begynde kl. 6, om vinteren $\mathrm{kl}$. 7. De måtte ikke lade fremmede komme ind i kancelliet, ej heller det øvrige hofpersonale. I den ed, som kancellisvendene skulle aflægge, blev de forskellige opgaver nævnt i rækkefølge. Svendene skulle læse korrektur på det skrevne, indføre teksten $\mathrm{i}$ registranterne (ingrossieren) og lave kopier efter de ordrer kansleren eller sekretæren gav. Kancellipersonalet fik kost og logi på slottet som det øvrige hofpersonale. 
Hertug Hans den Aldres sekretær eller kansler Georg (eller Jorgen) Beyer. Beyer var født $i$ Gera $i$ Sachsen $i$ 1522 og var gennem 33 år ansat hos hertugen $i$ Haderslev. Portrættet findes på Beyers epitafium i Marie kirke $i$ Flensborg. Foto $i$ Dansk Centralbibliotek for Sydslesvig.

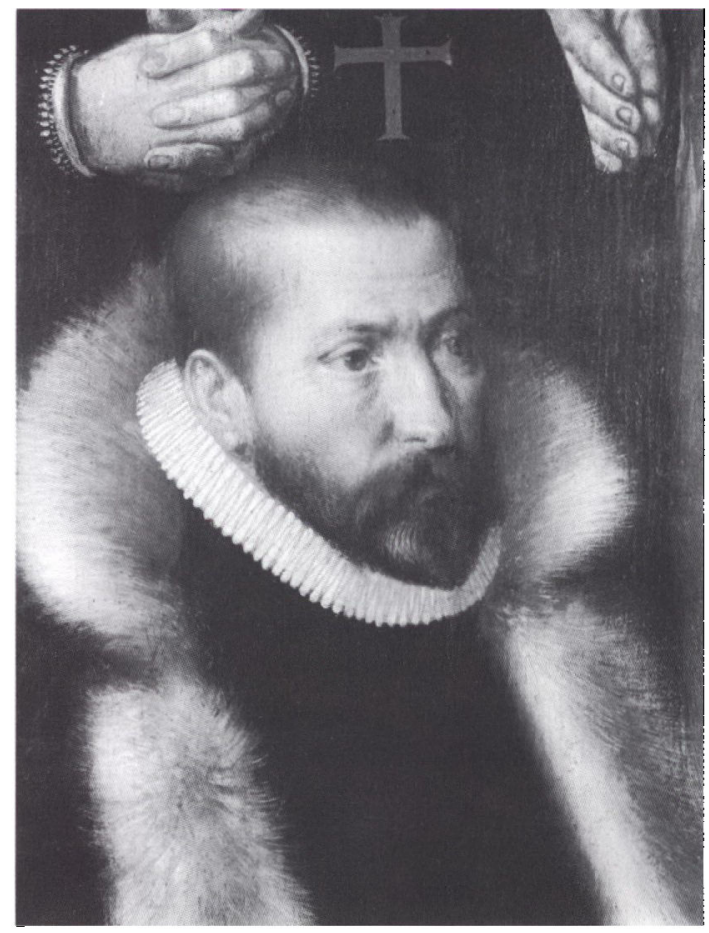

\section{Fyrstelig hofordning}

Den første forordning, som hertug Hans udstedte efter at han var begyndt at regere, var en hofordning, udstedt den 27 . august 1544 . Det vigtigste element $i$ den var en rangordning, der især havde betydning ved bespisningen, således at enhver kendte sin plads. Der var også en bestemmelse om, at personalet skulle holde sig fra køkken og kælder, hvis den enkelte ikke havde fået udtrykkelig ordre fra hofmesteren eller marskallen til at komme der. Hofordningen blev fornyet med visse mellemrum efterhånden som staben blev udvidet. Det viste sig nødvendigt at indskærpe god bordskik. Det hed i en tilføjelse, at de spisende $\mathrm{i}$ hofstuerne skulle forholde sig roligt og redeligt, og at ingen under måltiderne måtte kaste med kød, brød, fisk, knogler eller andet. Man kunne nok have lyst til at se de situationer, der gav anledning til denne bestemmelse.

En fyrstelig hofholdning krævede store forsyninger, og hertug 
Hans begyndte på bar bund. For at hjælpe ham skænkede kongen ham to læster sild. En læst var $30 \mathrm{hl}$. fordelt på 12 sildetønder. Hertugen var klar over, at det ikke var nok til vinteren, så for egen regning købte han yderligere 3 læster. Sildene blev købt i Falsterbo og sendt med skibe til Haderslev. Kongen skænkede også sin bror $100 ø k s n e$.

Der skulle også ansættes køkkenpersonale; det må have været svært at få en god kok, for hertugen skrev til søsteren og svogeren i Königsberg, om han ikke kunne få kokken Krakofzski som mundkok, men ham ville hertugparret nu ikke undvære.

I de forste år slog hertug Hans sig til tåls med de trange forhold på Haderslevhus, men han blev $\mathrm{i}$ årenes løb økonomisk bedre stillet. Det var som nævnt en periode med gode konjunkturer. I 1557 besluttede han at bygge sig et standsmæssigt slot. Han gav det navnet Hansborg. Arbejdet strakte sig over mange år; i 1566 blev slotskapellet indviet; men der blev bygget videre, så længe hertug Hans levede, ja, byggearbejderne fortsatte også efter 1582, da kong Frederik II som sin arv efter hertug Hans havde overtaget Haderslev amt.

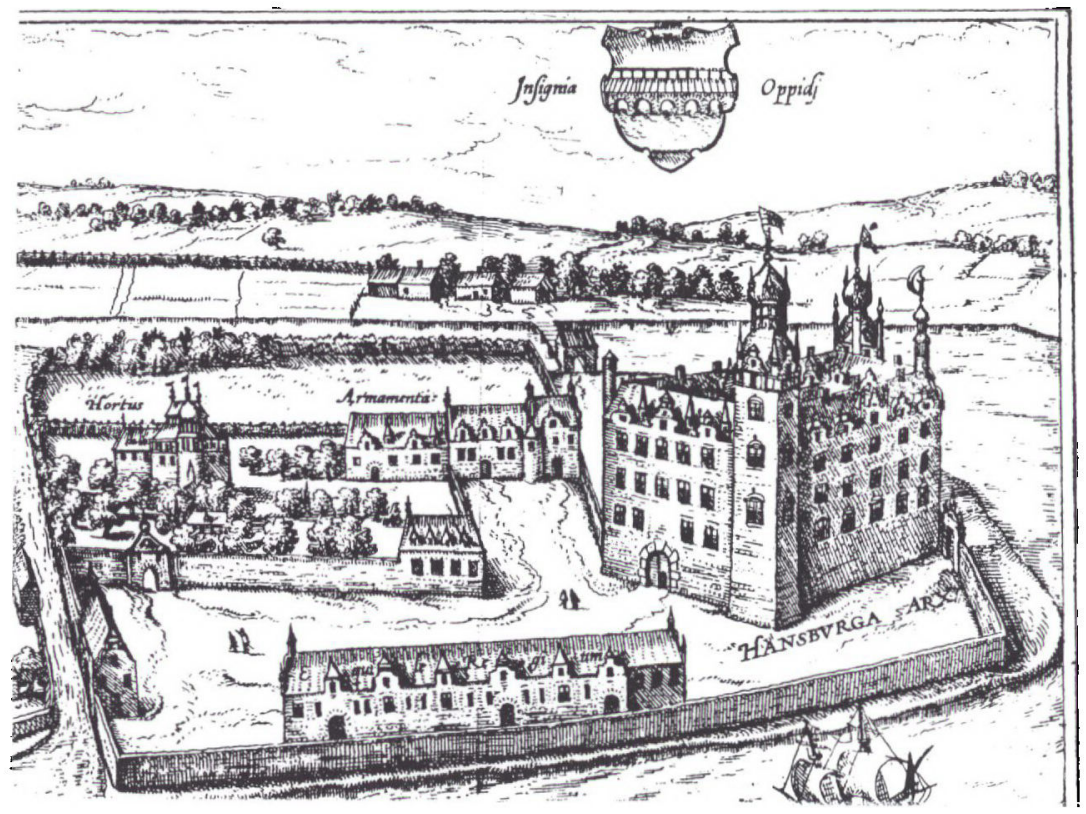

Slottet Hansborg kendes fra dette stik $i$ Braun og Hogenbergs vark om de nordeuropæiske byer: Theatrum Urbium, 1585. Stikket er den eneste samtidige tegning, hoor Hansborg er afbildet. 
Som bygmester havde hertugen antaget Herkules von Oberberg, en af tidens anerkendte arkitekter. Man har billeder af Hansborg, men af selve slottet er der ikke blevet sten på sten tilbage. Slottet var en pryd for Haderslev, som i det hele taget nød godt af at være blevet residensby. Mange håndværkere flyttede til byen, hvor de blev "hofleverandører«.

Til de gode gerninger hører også, at hertug Hans i 1567 oprettede en latinskole i Haderslev. Som en selvfølge med tysk skolesprog, og det blev bevaret også efter at Haderslev fra 1582 kom til at lyde under danske konger. I 1569 grundlagde han et hospital; det var ikke et sygehus, men et sted, hvor fattige kunne finde et blivende sted.

\section{Hertug Hans' administration}

Almindeligvis er hertug Hans blevet betragtet som en mild fyrste. Efter tidens forhold var han det sikkert. På mange måder adskilte han sig fra sin mere stridslystne bror Adolf. Længe havde den frie bonderepublik Ditmarsken været en torn i øjet på hertug Adolf; det frygtelige nederlag i 1500 kunne nok være afskrækkende; men hertug Adolf havde planer om at erobre området, han var gerne gået i krig på egen hånd, men da hans planer blev kendt, var han nødt til at gå frem sammen med sine medfyrster. I 1559 blev Ditmarsken erobret, den sydlige del blev lagt til den kongelige del af Holsten, den nordlige fik hertug Adolf, og Hans fik det mellemste stykke. Det var den eneste egentlige krig hertug Hans deltog i.

Men hertugen var dog så meget barn af sin tid, at han som andre fyrster var ganske hård $\mathrm{i}$ kravene til sine undersåtter. Af bønderne var langt de fleste fyrstelige fæstere; det betød i realiteten, at de var arvefæstere og således ret betryggede $\mathrm{i}$ deres besiddelse; men de var pligtige til at påtage sig arbejdsopgaver på ladegårdene og ved offentlige anlæg.

Hertugen udvidede ladegården ved Haderslev og ligeledes ladegården ved Tørning ved Hammelev. Tørning var det centrale punkt $\mathrm{i}$ det såkaldte Tørninglen, svarende til det man senere har kaldt Haderslev Vesteramt.

Ikke nok med at ladegårdene blev udvidet og hovtjenesten dermed blev mere tyngende, han nedlagde desuden landsbyen Vojens og oprettede på landsbymarken Vojensgård. I 1573 erhvervede han herregården Refsø i Sommersted sogn, også her blev hovtjenesten udvidet. 
Men da et konsortium fra Nürnberg i 1566 foreslog ham nogle moderne metoder til at foroge udbyttet af ladegårdene, afviste han det med foragt. Det ville betyde store byrder for undersåtterne, og egentlig drejede det sig - sagde han - om et forslag til at drive åger, som var ukristeligt og forbudt af Gud. Så folkene fra Nürnberg måtte rejse hjem med uforrettet sag.

Fra første færd havde hertug Hans øjnene åbne for de inddigningsmuligheder, der var på Vestkysten. Han tog initiativ til en række digeslagninger, der betød afgørende indgreb i naturforholdene i marskområderne. Fyrsterne var jordhungrende og vest for Tønder var der muligheder for at udvide territoriet på fredelig vis.

I 1554 fik hertugen mod beboernes protester gennemtvunget, at der blev anlagt et dige fra Højer til Rudbøl og videre østpå til gesten ved Grelsbøl i Kær herred. Her blev for første gang løst en meget stor og krævende ingeniøropgave, idet Vidåen blev spærret af med en sluse. Flere tidligere forsøg var mislykket. Arbejdet var afsluttet i 1556. Det betød, at et stort marskområde blev indvundet til græsgange, men det betød også, at Tønder by blev afskåret fra havet. I byens våben ser man stadig et sejlskib, men det er et minde om en fjern fortid.

Hertug Hans havde nu fået blod på tanden, og i 1562 blev et nyt stort digeanlæg sat i værk, et dige fra Rudbøl over til Vidding herred, der indtil da havde ligget som en ø. Diget var færdigt i 1566. Det sidste store anlæg fra 1570 forbandt den sydlige del af Vidding herred med Kær herred ved Klægsbøl. I forhold både til forgængere og en del af efterfølgerne havde hertug Hans heldet med sig ved sine anlæg. Det gælder dog ikke digerne på Nordstrand, der blev totalt ødelagt og splittet ved den store stormflod i 1634.

De store inddigninger krævede et enormt arbejdsopbud, og de betød meget tyngende byrder for befolkningen. Til digeanlæggene skulle bruges omfattende mængder af buskværk og træ. Det betød rydning af et stort skovområde øst for Tønder. Det nævnes, at der til digearbejdet 1562-66 var brugt 18.000 læs træ af forskellig slags. Læssene var næppe store, men alene antallet giver et indtryk af hvilken tynge, der har hvilet på bondebefolkningen.

De store digeopgaver blev reguleret ved forordninger. I den samling af forordninger, som Emilie Andersen udgav, er det samlede antal 101, deraf havde 23 relation til digevæsen.

På det skovområde, der var ryddet øst for Tønder, oprettede hertug Hans en ladegård med et tilliggende på 1000 td. land. Avlsgården fik 
navnet Grøngård, og her kunne hertugen få afløb for sin store lidenskab, jagten. I 1568 besluttede han her at bygge et jagtslot; også her var Hercules von Oberberg bygmester. Det lille jagtslot blev flot udstyret. En inventarliste fra 1580 fortæller, at der var rigeligt med stueborde, stole, dragkister, slagbænke, klapsenge, panelskabe. Der var hængt grønt og rødt klæde på væggene, der iøvrigt var prydet med gevirer, horn og malerier (ialt 32). Også service og sengeudstyr var der rigeligt af.

\section{Lovgivning}

Hertug Hans var en landsfaderskikkelse og tog sig af sit lille område som en god husholder. Det gav sig bl.a. udtryk i en omfattende lovgivningsvirksomhed. Man kunne have ventet, at han gennem lovgivningen ville søge at skabe en vis enhed $i$ de spredte besiddelser. Det skete til en vis grad $i$ indholdet, men ikke $i$ formen. Forordninger udstedtes for amter og landskaber hver for sig. Der kunne også være tale om helt specielle lovgivningsemner, f.eks. landretten for Nordstrand.

De områder, hvor man kan følge en vis enhedslinje, gjaldt straffesystemet, kirkeordninger, sædelighed, åger, mønt og så forsøg på at stoppe overdrevent luksusforbrug.

Straffereglerne blev anlagt efter de retningslinier, der almindeligvis gjaldt i Tyskland. I 1545 blev der i Tønder amt indført dødsstraf i manddrabssager. Efter gammel nordisk ret havde man kunnet klare sådanne sager med bøder eller fredløshed. En anden ny straf rettede sig mod menedere. I alle hertugens områder skulle fra 1549 den regel gælde, at i sådanne sager skulle de to fingre, hvormed den falske ed var aflagt, afhugges. Særlig på Tønderegnen havde der været mange menedsager. I 1553 spurgte amtmanden, Christian Rantzau, om der ikke kunne træffes en mindelig ordning, eller om dommen skulle fuldbyrdes i sin strenghed. Hertugen svarede, at han egentlig onskede loven efterlevet, men da der var forskel på om den falske ed var aflagt af enfoldighed eller af ond vilje, så skulle amtmanden, når der var tale om enfoldighed først true med den fastsatte straf, men alligevel til sidst lade nåde gå for ret og kræve en bøde. Hvis en falsk ed var aflagt med overlæg, skulle straffen fuldbyrdes.

Straffen for ægteskabsbrud blev også skærpet. I visse tilfælde kunne ægteskabsbrud straffes med døden. Men i en sag fra Tønder, hvor 
en mand havde fået et barn med sin kones kusine, der var $i$ huset hos dem, reagerede hertugen på lignende måde, som i menedsagerne. Amtmand v. Thienen skulle true med skarpretteren, men kun som en trussel; til sidst skulle sagen ordnes med en bøde for mandens vedkommende, mens den kvindelige part skulle bortvises fra Tønder amt. Der blev ansat særlige "vrøgere«, der skulle holde øje med om reglerne i ægteskabsforordningerne blev overholdt. I vore dage ville man kalde dem dyneløftere.

På det kirkelige område kom der en lang række forordninger, det skyldtes ikke mindst, at kirken i de urolige tider under reformationen havde lidt tab. Dertil kom at bønderne var uvillige til at udrede tiende i »kærven«, altså aflevere hvert tiende neg, derfor måtte den gamle tiendeordning indskærpes.

Blandt forordningerne indtager de, der var rettet mod overdreven luksus en særstilling. Dels gjaldt de begrænsede områder, kun Haderslev by og øen Nordstrand, og dels var de udarbejdet i enkeltheder af de lokale råd. Hertugen meddelte i 1566 byrådet i Haderslev, at der herskede megen uskik, ødselhed og pengespild ved begravelser, bryllupper og barselgilder. Også klædedragten var for luksuspræget. Han onskede et forslag til en forordning. Det fik han.

Resultatet blev et totalt forbud mod gravøl, kun familiemedlemmerne og tyendet måtte våge over den afdøde. Naboerne kunne få lov at komme, men kun i al beskedenhed. Til barnedåb måtte kun indbydes fadderne og derudover 5 af vennerne, og der måtte kun serveres 4 retter mad, og der måtte kun drikkes øl, ikke vin. Blev flere indbudt skulle værten bøde med en gylden, hvis der blev serveret vin, var bøden 10 gylden. Sådan blev alle festlige begivenheder gennemgået og reguleret. Enkelthederne giver en beskrivelse af hverdag og fest i Haderslev hos høj og lav. Det var selvfølgelig helt umuligt at kontrollere de mange begrænsninger. Når denne forordning her får en lidt mere indgående omtale, skyldes det den iøjnefaldende forskel, der var på det fyrsterne ville unde deres undersåtter, og så den pragt hvormed familiehøjtider blev fejret af konger og hertuger.

\section{Opgaver for familien}

En af de første opgaver, der påhvilede hertug Hans, da han i 1543 var kommet hjem fra Königsberg, var det praktiske arrangement i forbindelse med søsteren Elisabeths bryllup med Hertug Magnus af 
Mecklenburg 26. august dette år. Magnus var verdslig biskop af Schwerin. Hertug Albrecht af Preussen, der havde været højmester for den tyske ridderorden, var gået over til protestantismen og omdannede ordenslandet til et hertugdømme. På samme måde opgav hertug Magnus den katolske tro og giftede sig. Han var da 34 og prinsesse Elisabeth 19 år gammel. Uanset de vanskelige tider, hvor Danmarks rige endnu var i krig med kejser Carl, blev der lagt op til et stort bryllup i Kiel. Festen blev finansieret ved en særlig skat, kaldet frokenskat.

Forberedelserne begyndte $\mathrm{i}$ april 1543. På slottet $\mathrm{i}$ Kiel residerede enkedronning Sophie; her skulle festen holdes, men slottet var ikke $i$ god stand, der måtte bygges et nyt køkken, og der måtte skaffes tæpper og tapeter til at pynte op med i dansehuset og gemakkerne, hvor de fyrstelige gæster skulle bo.

Man regnede med at skulle skaffe havre til 2000 heste; kornet måtte man have fra kongeriget. På torvet i Kiel skulle arrangeres en ridderturnering. For at få plads måtte skomagerboderne nedrives, hvad bystyret kviede sig ved; men der hjalp ingen kære mor. De deltagende skulle være ensartet påklædt, og mønstre blev sendt ud til hver enkelt. Hertug Hans ville også selv deltage i turneringen, men han havde ingen egnet hest; så han bad fruen på Haseldorp om at låne en hingst, der skulle være særlig god til turneringsridt.

Bystyret $\mathrm{i}$ Kiel følte sig hårdt presset, fordi borgerne $\mathrm{i}$ forvejen var tynget af indkvarteringer. I anledning af krigen var der mange landsknægte $\mathrm{i}$ byen. Men uanset dette blev der stillet store krav både til adelige og borgere. Det blev pålagt de større byer, deriblandt Flensborg, at stille tinfade, tallerkener og bordduge til rådighed til 16 borde. To fruer skulle følge med, så de kunne holde opsyn med genstandene. De skulle også dække bordene og rydde op bagefter.

Hertug Magnus skildres som en lærd, men svagelig mand. Han døde i 1550 uden at der var født børn i ægteskabet. Elisabeth havde nogle svære år, indtil hun i 1556 blev gift med sin første ægtefælles nevø, hertug Ulrik, der havde efterfulgt onklen i Schwerin. I dette ægteskab blev der født en datter, der efter sin mormor kom til at hedde Sofie. Hun blev dronning af Danmark, gift med Frederik II og gennem datteren bevarede Elisabeth en nær kontakt til Danmark. Hun døde i Gedser i 1586 og ligger begravet i domkirken i Güstrow.

Hertug Hans har været et udpræget familiemenneske, han opholdt sig ofte ved det danske hof og fik også her udløsning for sin jagtglæ- 


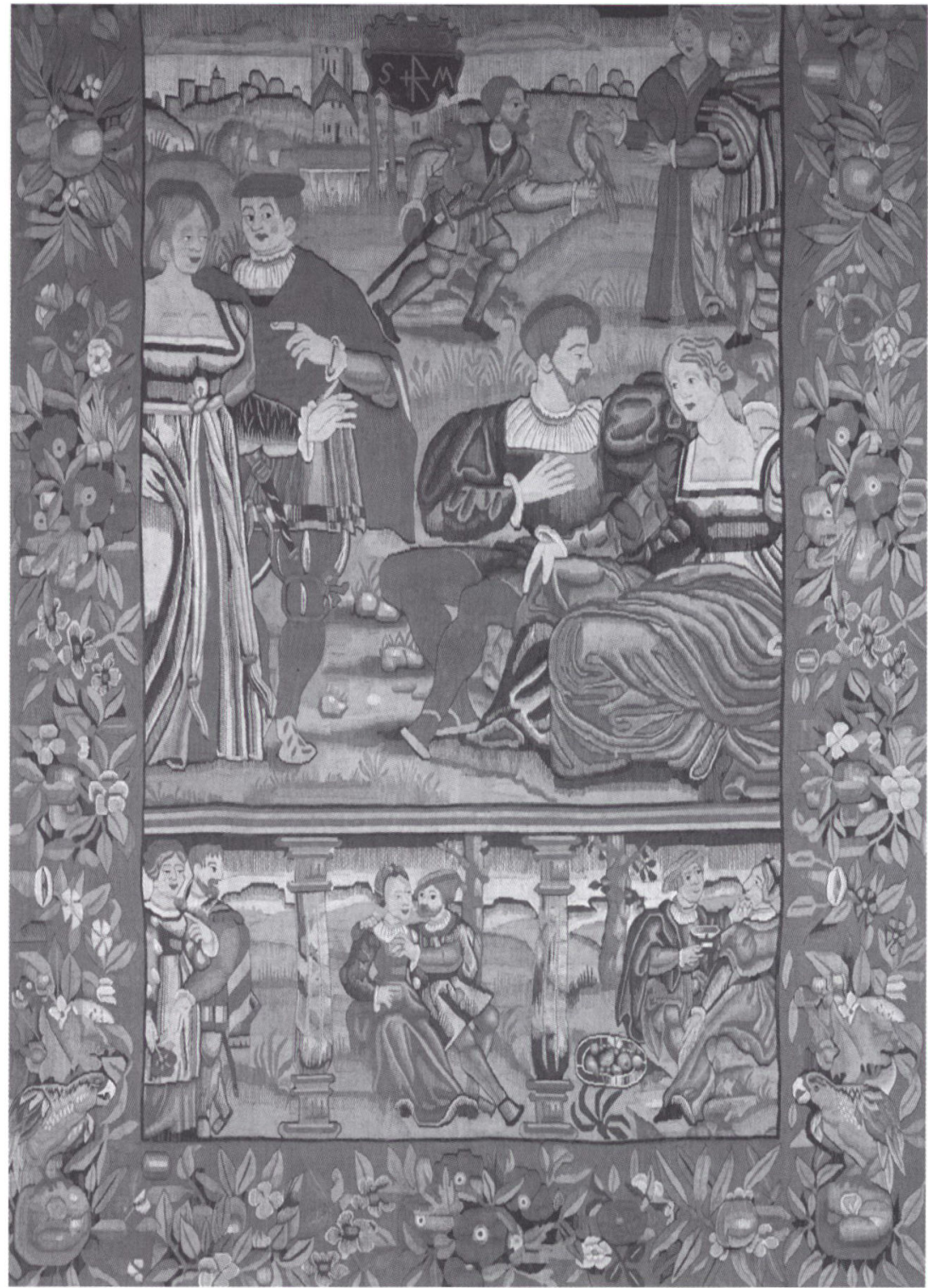

Gobelin som hertug Hans lod fremstille til Hansborg slot $i$ anden halvdel af 1500tallet. Efter slottets brand kom det kostbare txppe i Haderslev Frue Kirkes besiddelse. I dag findes det i Städtisches Museum i Flensborg. Foto i Haderslev Museum. 
de, når han fulgtes først med sin bror Christian og senere med sin nevø Frederik II.

I de perioder, han tilbragte i kongeriget, var Iver Reventlow hans stedfortræder hjemme. I 1549 var han en tidlang først i Kolding, så i Odense, derpå i København og til sidst i Assens. Han var borte i mindst 9 måneder. I 1552 var han kun i sit hertugdømme et par dage.

I 1548 fik hertug Hans overdraget den opgave at ledsage sin niece prinsesse Anna til Thorgau i Sachsen, hvor hun i august skulle giftes med hertug August. Hendes mor, dronning Dorothea, var med på turen. En sådan rejse krævede store forberedelser, og det ser ud til, at hertugen har skullet betale sin deltagelse selv. På rejsen blev han ledsaget af Godske Rantzau og Christian Rantzau. De skulle hver stille med seks heste, og de fik prøver tilsendt på det stof, de skulle bruge til deres tøj. Hertugen fik dog sine udgifter dækket ved en ekstraskat. Han begrundede skatten med nogle udgifter til en militær indgriben i Bremen stift, men nævnte også, at han stod for at gøre set hastigt tog udenlands «. Det var i maj 1548, men i juni havde han fået samvittighedsskrupler, hvad angik det tog, han havde talt om, det var nemlig brudefærden til Sachsen, det drejede sig om. Så han gav kontraordre; men da var man igang med at indkræve pengene, og undersåtterne havde ikke beklaget sig, så de fik altså lov til at betale gildet. Som hertuginde Elisabeth i Mecklenborg fik hertuginde Anna en høj stjerne hos befolkningen i Sachsen, hvor hun omtaltes og mindedes som "Mutter Anna«. Som Elisabeth bevarede også Anna en nær tilknytning til familien i Danmark.

Hertug Hans blev aldrig gift, og der findes ikke vidnesbyrd om, at han skulle have illegitime efterkommere; men han havde én stor kærlighed, og den gjaldt hans svigerinde dronning Dorothea af Danmark. Hun var 10 år ældre end han. Hvornår kærligheden spirede, ved man ikke; men da Dorothea i 1559 var blevet enke, tog hun ofte ophold på Koldinghus, der ligesom Randersgård, Sønderborg og Nordborg hørte til hendes livgeding.

Hertug Hans og dronningen viste hinanden megen hengivenhed, og de drøftede også muligheden af at kunne indgå ægteskab. Frederik II blev spurgt, og han overlod sagen til parternes egen samvittighed, og den bød dem at spørge forskellige teologer til råds, men disse tog imidlertid afstand fra planen. Dronningen drøftede så sent som i 1567 sagen med sin skriftefader, magister Paul, der anbefalede hende igen at spørge fremmede lærde mænd; selv syntes han nærmest at have 
været for planen. Han svigtede senere sin tavshedspligt, og dronningen forklarede i et brev til sin søn Frederik II, hvorledes sagen hang sammen. Den bevarede brevveksling mellem hertug Hans og dronning Dorothea giver mange vidnesbyrd om de varme følelser, de nærede for hinanden; men ægteskab blev det ikke til. Dronning Dorothea døde i 1571.

1560'erne havde været vanskelige år for Danmark på grund af den nordiske krig 1563-70. De sønderjyske hertuger gjorde, hvad de kunne for at holde sig uden for, men krigens følger sporedes også i deres områder.

1570 'erne var fredelige år med god fremgang for riget. Som tidligere nævnt forhandlede man om hertugernes lensforpligtelse over for Danmark. Det endte med lenshyldningen i Odense i 1580.

Ligesom spørgsmålet om lenspligten trak ud i årevis, således forhandlede man i tre årtier om de vanskeligheder, der var forbundet med, at Haderslev Vesteramt (Tørninglen) i kirkelig henseende hørte under bispen i Ribe og dermed kongen af Danmark, mens området $\mathrm{i}$ verdslig henseende hørte under hertug Hans. Striden blev henskudt til en voldgift med tyske fyrster som opmænd. Det førte til, at hertug Hans på mange områder fik medhold. I Tysklands protestantiske egne var den verdslige magt styrket på den kirkeliges bekostning. Forliget, der gav hertug Hans visse indrømmelser, blev sluttet i Kolding i 1576, men det blev af kort varighed, for den 2. okt. 1580 døde hertug Hans; det lille hertugdømme blev delt, Kongen fik Haderslev amt og hertug Adolf fik Tønder amt med Løgumkloster.

\section{Hertugens død og arvedelingen}

Delingen blev dog først gennemført efter næsten to års bitre stridigheder mellem kongen og hertug Adolf. Straks da kongen først i oktober 1580 erfarede dødsfaldet, traf han forberedelser til, at hertugen skulle begraves den 2 . december. Ikke mindre end 44 gode adelsmænd blev

Efter Hertug Hans' død i 1580 flyttede den mangeårige kansler Georg Beyer til Flensborg. Han døde $i$ 1587, og fire år efter opsattes dette pragtfulde epitafium over Beyer og hans familie i Marie kirke. Beyer og de to hustruer ses knælende ved korsets fod, bagest den første hustru Maria Beyers, født Frees, og i forgrunden den anden hustru Magdalena (d. 1598). I baggrunden af billedfeltet ses et topografisk meget nøjagtigt prospekt af Flensborg by med Duborg slot lengst til højre. Foto i Dansk Centralbibliotek for Sydslesvig. 





opfordret til at møde i Kolding 25. november 1580, hvor også rigsrådet skulle indfinde sig, for derfra at begive sig til Haderslev og ledsage den afdøde hertugs lig til Slesvig, hvor bisættelsen skulle finde sted. Men den 2. november 1580 kom der kontraordre, begravelsen var udsat på ubestemt tid. Det var hertug Adolf, der her var på spil. Han sendte straks efter dødsfaldet folk til Hansborg for at have kontrol med værdierne. Han foreslog i begyndelsen af november 1580 overfor kongen, at der før begravelsen skulle forhandles mellem dem om arven. Men kongen ville ikke forhandle om arven, før begravelsen havde fundet sted, og han foreslog nu, at hertug Hans skulle have sit sidste hvilested i Frue Kirke i Haderslev. Kongen foreslog, at begravelsen skulle finde sted fire uger efter jul. Gennem Kancelliets brevbøger kan man følge slagets gang.

Hvad angik stedet, fik hertug Adolf dog medhold, hertug Hans blev begravet i Slesvig domkirke. Den 11. februar 1581 begyndte ligfærden sydpå fra Haderslev; første dag nåede man til Rise, ved Rødekro, næste rast holdt man i Flensborg; den 13. nåede processionen Slesvig, og den 14. fandt selve begravelsen sted. Blandt deltagerne $i$ færden var talrige præster fra Haderslev og Tønder amter. Blandt dem var også den unge Jacob Fabricius, der senere blev generalprovst for den gottorpske del af hertugdømmerne. Han udarbejdede en udførlig beretning om højtideligheden, men den er desværre ikke bevaret. Jacob Fabricius har i sine erindringer oplyst, at hertugens kansler Hieronymus Oelgardt på kongens befaling blev taget som fange, da han på hjemrejsen ved Helligbæk kom ind i den kongelige del af Slesvig. Kongen havde overdraget opgaven til rigsmarsken Peder Gyldenstierne, som havde været med ved forhandlingerne i Kolding i 1576 og i forberedelserne til lenshyldningen i Odense i 1580. Jacob Fabricius oplyser, at Oelgardt beskyldtes for at have anstiftet ufred mellem kongen og hertugen. Noget kunne tyde på, at han $i$ interregnet var gået hertug Adolf til hånde. Siden hørtes ikke mere til Hieronymus Oelgardt.

Sekretæren Georg Beyer, der havde tjent hertug Hans siden 1547, flyttede til Flensborg, hvor han døde i 1587. Hans pragtfulde epitafium pryder endnu Mariekirken.

Forhandlingerne om arvedelingen blev fort på den ene side af Niels Kaas og Jørgen Rosenkrands, på den anden side af Benedikt Ahlefeldt og Ditlev Rantzau. De kunne ikke nå til enighed, og sagen blev henskudt til voldgift med tyske fyrster som opmænd. Den 14. august 


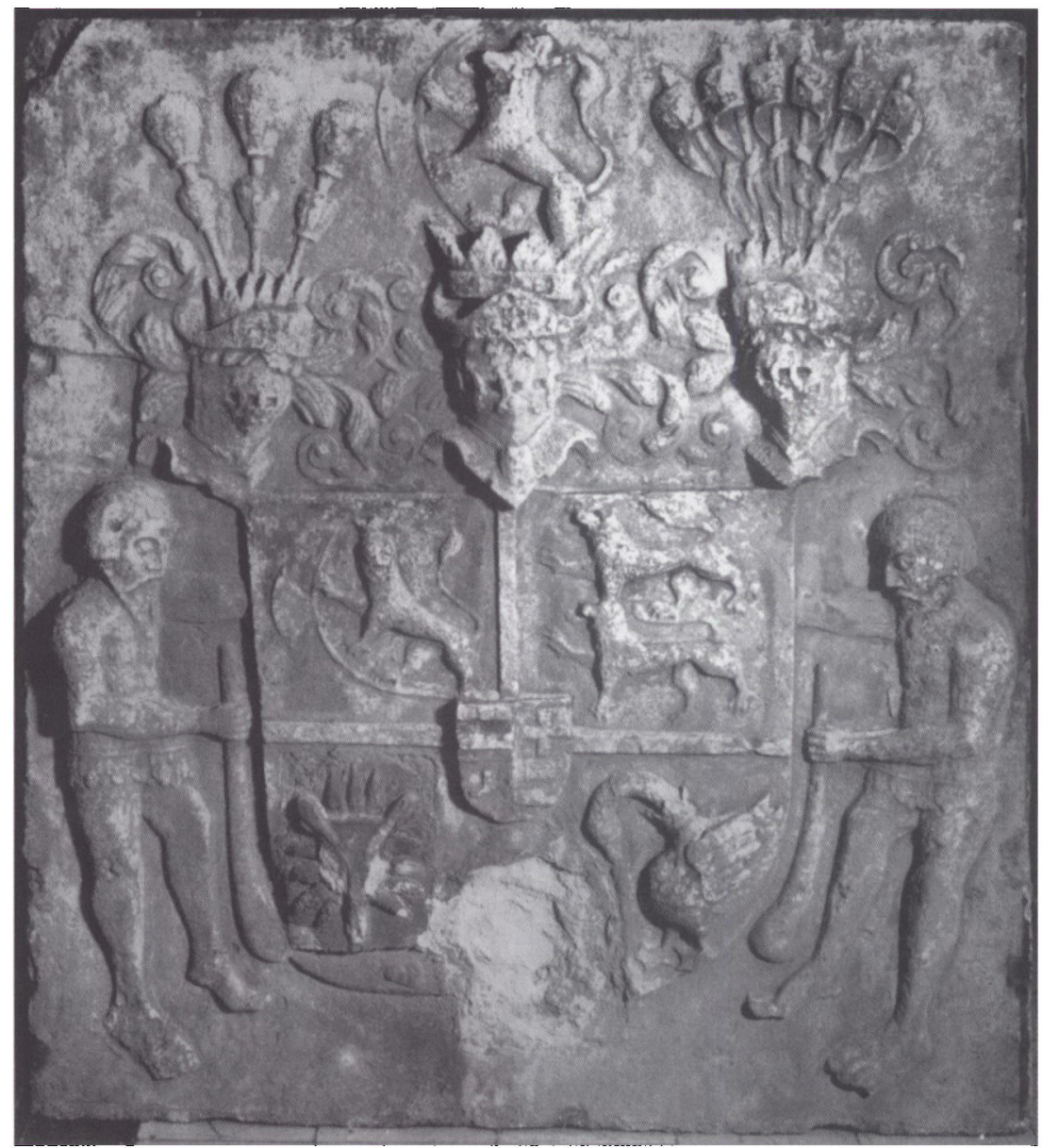

I 1559 erobrede hertugerne Adolf og Hans den Aldre sammen med kong Frederik 2. Ditmarsken. Det medforte, at Hans måtte udvide sit våbenskjold med Ditmarskens rytter for at kundgøre, at det rige Ditmarsken nu horte til hans besiddelser. På hertugvåbenet ovenfor har Ditmarsken-feltet været primitivt tilføjet forneden under midterskjoldet. Tilføjelsen var dog af så dårlig kvalitet, at den senere er forvitret bort. Våbenskjoldet stammer måske fra det gamle Haderslevhus, evt. fra hertug Frederiks, den senere kong Frederik 1.s, tid. Det blev derefter benyttet på hertug Hans' latinskole $i$ Haderslev. En kopi kan $i$ dag ses indmuret på Haderslev Katedralskole. Foto $i$ Haderslev Museum.

1581 nåede man til enighed, hertug Adolf fik alt løsøret, Haderslev og Rendsborg amter gik til kongen, hertug Adolf fik Tønder amt med Løgumkloster og Nordstrand og Femern. Hertug Hans den Yngre fik 
til udligning af sine krav Ryd kloster, som hidtil havde været kongens. Her byggede han Lyksborg slot.

Hertug Hans den ældre repræsenterer en parentes i Sønderjyllands historie, men i Haderslev mindes man med passende mellemrum både hertugen og den tid, da der eksisterede et hertugdømme Slesvig-Holsten-Haderslev.

\section{LITTERATURLISTE}

Caroline Emilie Andersen: De Hansborgske registranter I-II. Udgivet af Kildeskriftselskabet 1943-49.

K. Hansen: Hertug Hans den Eldre i Haderslev. Historisk Tidsskrift 4 R. VI. 1877-78, s. 341-428.

A. Heise: Et Bidrag til den Københavnske Herredags Historie. Historisk Tidsskrift 4 R. IV. 1873-74, s. 634-642.

Iselin Gundermann: Herzogin Dorothea von Preussen. 1965.

Samling af Dronning Dorotheas breve, i: Aarberetninger fra det Kongelige Geheimearchiv I 1852-1855, s. 69-214 og III 1860-1864, s. 3-104.
H. Stiesdal: Grøngaard. Hertug Hans den Ældres Jagtslot, i: Fra Nationalmuseets Arbejdsmark 1956, s. 115-127.

V. Leick: Grøngaard Jagtslot, i: Sønderjysk Månedsskrift 1950, s.85-87.

En udførlig redegørelse for kilder og litteratur vedr. Hertug Hans den \#ldre findes i tilknytning til Jørgen Steen Jensens og Dieter Lohmeiers biografi af hertugen i: Biographisches Lexikon für Schleswig-Holstein und Lübeck Bd. 7 (1985), s. 91f.

Også i artiklen om Hertug Hans den Fldre i Dansk Biografisk Leksikon bd. 5 (1980) s. 547-549 findes supplerende litteratur- og kildehenvisninger. 